\title{
Soil Protection in the EU According to the Directive on Industrial Emissions (IED) and Croatian Practice
}

\author{
Ivan Pilaš ${ }^{1 凶}$, Nikolina Bakšić ${ }^{2}$
}

\author{
${ }^{1}$ Croatian Forest Research Institute, Cvjetno naselje 41, 10450 Jastrebarsko, Croatia \\ 2 Oikon Ltd Institute for Applied Ecology, Trg senjskih uskoka 1-2, 10020 Zagreb, Croatia \\ $\checkmark$ Corresponding author: e-mail: ivanp@sumins.hr
}

Citation:

PILAŠ I, BAKŠIĆ N 2014 Soil Protection in the EU According to the Directive on Industrial Emissions (IED) and Croatian Practice. South-east Eur for 5 (1): 53-64. DOI: http://dx.doi.org/10.15177/seefor.14-01

\begin{abstract}
Background and Purpose: Soil protection against pollution in EU is mostly covered in a new Directive on industrial emissions (IED), adopted on November 24, 2010 as a follow up of the IPPC Directive. For all industrial facilities that fall under IED, the Directive obliges the establishment of a complex system of management of contaminated soil at the national level, in order to facilitate the implementation of the principle of "polluter pays" furthermore to reduce the risk of contamination of soil and groundwater.

Material and Methods: This paper presents an overview of soil management system that should be established in each EU country to fulfil IED requirements. It consists of a meta-analysis of IED requirements and current state and drawbacks of soil protection in Croatia including present state of legislation, responsibility of authorities, soil surveys and remediation activities.

Results and Conclusions: IED set the obligation on the industrial operator before the start of production to prepare a report on the initial state of soil as a necessary requirement for obtaining environmental permit. It set obligations for monitoring of soil and groundwater status in the location of industrial facility for a period of ten (soil) and five years (groundwater). After the cessation of production, and in the case of exceeding critical limits of pollution, the operator is obliged to perform remediation or restitution of land in the state as it was at the beginning of production. Management of contaminated soil according to IED requirements obliges the Croatian government to establish a complex multi-level system. At first it requires better definition of responsibilities between two ministries; Ministry of Environmental and Nature protection and Ministry of Agriculture. IED requires enactment of adequate legal basis (i.e. Soil protection act) and the establishment of operational instruments for the implementation of soil protection, such as a register of contaminated soils and the accreditation of soil remediation experts.
\end{abstract}

Keywords: Soil pollution, Directive on industrial emissions (IED), Soil protection, monitoring, remediation

\section{INTRODUCTION}

The responsibility to protect soils in Croatia arises primarily from the Environmental Protection Act [1], which established protection grounds: (i) Soil protection comprises retention of health and functions of the soil, prevention of soil damage, monitoring the quality of soil 
and restoration of damaged soils and land, (ii) contamination or damage to the soil are considered to have a detrimental impact on the environment, and the creation of acceptable limits of soil quality should be manifested in specific regulations. Penalties for long-lasting and significant deterioration of the quality of the soil through the input of pollutants, what thus leads to endangering of people's health, are stipulated in addition to the concept of "polluter pays", also in the Criminal Act of the Republic of Croatia [1]. However, to the present time, further development of the soil management, throughout the provision of acceptable limits, soil monitoring as well as follow up remediation of contaminated sites in Croatia is still not resolved as it should be according to the Environmental Protection Act [2].

Apart from the environmental protection act, soil protection in the Republic of Croatia has been mainly implemented through sectors such as agriculture and forestry, particularly through case study assessments [3, 4, 5]. Soil pollution is also mainly considered together with air pollution where international programs, such as forest ecosystem monitoring and ICP-Forest (http://icp-forests. net/), are implemented together with similar vegetation monitoring activities $[6,7,8]$. In respect with the state of development of respective legislative in Croatia, a significant shift has been made in the agricultural sector, inside the framework of Agricultural Land Act [9] and associated regulations; The Regulation on the protection of agricultural land from pollution [10], the Regulation on standards for determination of exceptionally valuable arable (P1) and valuable arable (P2) agricultural land [11], and the Ordinance on the methodology for the monitoring of agricultural land [12]. In 2010, national centres responsible for the implementation of continuous monitoring of agricultural and forest land were established. According to the Regulation on the methodology for the monitoring of agricultural land [12], the responsible authority for monitoring of the condition of agricultural soils is "Croatian Centre for Agriculture, Food and Rural Affairs - Department of Soil and Land Conservation" (now the Agency for Agricultural Land), while, according to the Regulations on monitoring of the state of damage of forest ecosystems, including soil [13], under the Forests Act [14], the responsible authority is the Croatian Forest Research Institute as an ICP-Forest National Focal Centre. Under the Forestry Act, however, soil protection is not explicitly specified in any of the related regulations [13].

From July 2013, the Republic of Croatia is a full member of the European Union, and it has committed itself to align with the EU acquis (acquis communautaire). This means that Croatia must accept the founding treaties and other materials derived from the contract and to align its legislation with the EU acquis. EU membership obliges Croatian authorities to adopt and harmonize the legislation concerning also the protection of the soil in the frameworks of environmental protection and sustainable development. Both in Croatia and the EU, soil is mostly encompassed inside various sectorial directives [15]. Up to the present stage, in the EU, there is no unified legislation comprised within a separate directive regarding soil. Long-standing initiatives related to soil protection in the EU has so far resulted in two key documents adopted in 2006; Thematic Strategy for Soil Protection [16], and a proposal for a framework directive on soil protection [17]. Although, since 2007, there have been undergoing discussions at the EU level between Member States, up to the present moment, no common agreement in terms of the "Soil directive" has been reached. After the Spanish presidency in 2010, soil issue was no longer placed on the agenda for further discussion. Despite that, the absence of a common "Soil directive" slightly diminishes the perception of importance of soils in the EU, soil protection is a rather important issue, functionally established in a series of sectorial directives. Soil is entangled inside the Habitats Directive [18] which defines the protection of natural habitat types. 
Soil protection in agriculture is regulated with a cross-compliance policy $[19,20]$ that links a number of EU directives and provisions of subsidies for farmers with the obligation of applying the principles of good agricultural practice. However, one of the newest and particularly important acts for soil protection against contamination is presented in the Directive on industrial emissions (IED) [21], adopted on November 24, 2010 as a follow up of the IPPC Directive (Integrated Pollution Prevention and Control). For all industrial facilities that fall under the IED, the Directive obliges the establishment of a complex system of management of contaminated soil at the national level in order to facilitate the implementation of the principle of "polluter pays" and furthermore to reduce the risk of contamination of soil and groundwater.

This paper introduces the most important IED requirements for member states regarding the protection of soil against industrial pollution as well with the comprehensive soil management system that has to be established accordingly. This paper also provides an overview of gaps identified in the current system of governance of contaminated soils in Croatia.

\section{MATERIAL AND METHODS}

\section{An overview of the Directive on Indus- trial Emissions (IED)}

Directive 2010/75/EU on industrial emissions (integrated pollution prevention and control - IPPC) builds and recast: the EU directive on waste from the titanium dioxide industry, the EU directive on limitation of emissions of volatile organic compounds (VOC) due to the use of organic solvents, the Directive on the incineration of waste, the Directive on the limitation of emissions of certain pollutants into the air from large combustion plants and the Directive on integrated pollution prevention and control (IPPC). It is based on the prevention and reduction of pollution at source by the principle of "polluter pays". Different approaches for controlling emissions into air, water and soil separately may encourage the shifting of pollution from one environmental medium to another rather than protecting the environment as a whole. The Directive provides an integrated approach for the prevention and control of emissions into air, water and soil, for waste management, for energy efficiency and for accident prevention. The Directive is going to clarify the provision, reduce unnecessary administrative burdens and implement the conclusions of the Commission related to the Thematic strategy on air pollution, the Thematic strategy for soil protection and on the Thematic strategy for the prevention and recycling of waste. It relies on the Sixth Environmental Action Programme of the EU from 2002.

Each installation should operate only if it holds a permit or, in the case of certain installations and activities using organic solvents, if it holds a permit or if it is registered. It is on the Member States to determine the approach for assigning responsibility to operators of installations provided that a compliance with this Directive is ensured. Member States may choose to grant the permit to one responsible operator for each installation or to specify the responsibility amongst several operators of different parts of an installation. In order to facilitate the granting of permits, Member States should be able to set requirements for certain categories of installations in general binding rules. It is important to prevent accidents and incidents and limit their consequences. Liability regarding the environmental consequences of accidents and incidents is a matter for the relevant national law and, where applicable, other relevant Union laws. In order to avoid duplication of regulation, the permit for an installation covered by Directive 2003/87/ EC of the European Parliament establishing a scheme for greenhouse gas emission allowance trading within the Community should not include an emission limit value for direct emissions of the greenhouse gases. 
This Directive does not prevent Member States from maintaining or introducing more stringent protective measures.

Operators should submit permit applications containing the information necessary for the competent authority to set permit conditions. Operators should be able to use the information resulting from the application of the Council Directive 85/337/EEC of 27 June 1985 on the assessment of the effects of certain public and private projects on the environment and of the Council Directive 96/82/EC of 9 December 1996 on the control of major-accident hazards involving dangerous substances when submitting permit applications. The permit should include all the measures necessary to achieve a high level of protection of the environment as a whole and to ensure that the installation is operated in accordance with the general principles governing the basic obligations of the operator. The permit should also include emission limit values for polluting substances, or equivalent parameters or technical measures, appropriate requirements to protect the soil and groundwater and monitoring requirements. Permit conditions should be set on the basis of best available techniques. In order to determine best available techniques and to limit imbalances in the Union regarding the level of emissions from industrial activities, reference documents for best available techniques (hereinafter BAT reference documents') should be drawn up, reviewed and, where necessary, updated through an exchange of information with stakeholders. The Commission should, through a committee procedure, establish guidance on the process of data collection, on the elaboration of BAT reference documents and on their quality assurance. The Commission should aim to update BAT reference documents no later than 8 years after the publication of the previous version.

The Commission should establish a forum that operates in a transparent manner. Practical arrangements for the exchange of information and the accessibility of BAT reference documents should be laid down, in particular to ensure that Member States and stakeholders provide data of sufficient quality and quantity. It is important to provide sufficient flexibility to competent authorities to set emission limit values that ensure that, under normal operating conditions, emissions do not exceed the emission levels associated with the best available techniques. In order to take into account certain specific circumstances where the application of emission levels associated with the best available techniques would lead to disproportionately high costs compared to the environmental benefits, competent authorities should be able to set emission limit values deviating from those levels. Such deviations should be based on an assessment taking into account well-defined criteria. The emission limit values set out in this Directive should not be exceeded. In any event, no significant pollution should be caused and a high level of protection of the environment taken as a whole should be achieved.

\section{RESULTS AND DISCUSSION}

\section{Obligations to Protect Soil and Ground- water from Contamination by IED}

IED in Article 12 Section 1.e. stipulates that all Member States take measures in issuing new environmental permits as well as at the closing of industrial activities, to provide an assessment of baseline soil contamination (baseline report). When the activity involves the use, production or release of relevant hazardous substances and there is a possibility of contamination of soil and groundwater in the area of installation, the operator shall prepare and submit a report to the Authority on the initial state (baseline report) before starting the operation or before the license is renewed for the first time after 7 January 2013. Report on the initial state should contain all the necessary information from which it can determine the state of soil and groundwater with respect to contamination, in order to make a quantitative comparison 
with the state of soil and groundwater after definitive cessation of industrial activities.

Report on the initial state (baseline report) must contain at least:

(a) Information on the current usage of the site and the information, if any, on how land has been used in the past.

(b) Existing information on the measured quality and condition of the soil and the groundwater status that reflect the state when the report was assembled, alternatively, a new quantitative analytical measurements of soil and groundwater, for those substances, of which there is a potential risk of contamination from the manufacture or accompanying emissions should be attached.

If there are information on the state of soil and groundwater, made under the national legislation, and which meet the requirements of this Directive, they may be attached to the report in the initial state.

The European Commission will establish guidelines on the content of the baseline report.

- IED in Article 14 also establishes permit conditions for supporting activities such as protection of soil and groundwater through monitoring the impact of the management of industrial waste produced during operation of the installation.

- IED lays claim to "permanent monitoring" of soil and groundwater as defined in Article 16. Monitoring of groundwater status will be conducted at least once every five years while the monitoring of soil has to be done at least once every ten years.

- IED establishes measures for the soil to be taken after the closure of industrial plants in Articles 22.3 and 22.4.:

After the final closure of the manufacturing plant, the operator will make an assessment of the state of soil and groundwater contamination from pollutants used, produced or discharged from the system.
Where the operation has caused significant pollution of soil and groundwater, which can be seen by comparing current state results with those of the report on the initial state (baseline report), the operator is obliged to take all relevant measures to rehabilitate the pollution and to return the land to the state before the start of production.

After the end of production, and where contamination presents a significant risk to human health and the environment, the operator shall take the necessary measures to eliminate or reduce pollution of soil and groundwater (remediation) so that such land ceases to pose a significant risk.

\section{Management of Contaminated Soil According to IED, the Case Study of Flanders}

The establishment of an efficient system for the protection of soil and groundwater from contamination by IED, requires the establishment of a functional organizational framework at the state level, which consists of the legal framework that defines in detail the protection of soil and other instruments for the implementation of policies such as the register of contaminated soils; soil certificates; soil standards; assurances for financing; accreditation of soil experts [22]. As a functional example of the establishment of such effective and developed system, one can examine existing Flemish management system for contaminated soil from which the established solutions are partially transferable. The disclosure of Flemish system is briefly outlined below.

Flemish system for management of contaminated soil is defined in the regulations and the Decree on soil remediation and protection [23], adopted at $14^{\text {th }}$ December 2007, aimed on protecting the soil from contamination and damage. The goals of protection strive towards improving the condition of soil close to the natural, unpolluted environment. The Decree regulates the obligation of removing the "historical" pollution over the period of the past 40 years as well as prevention and 


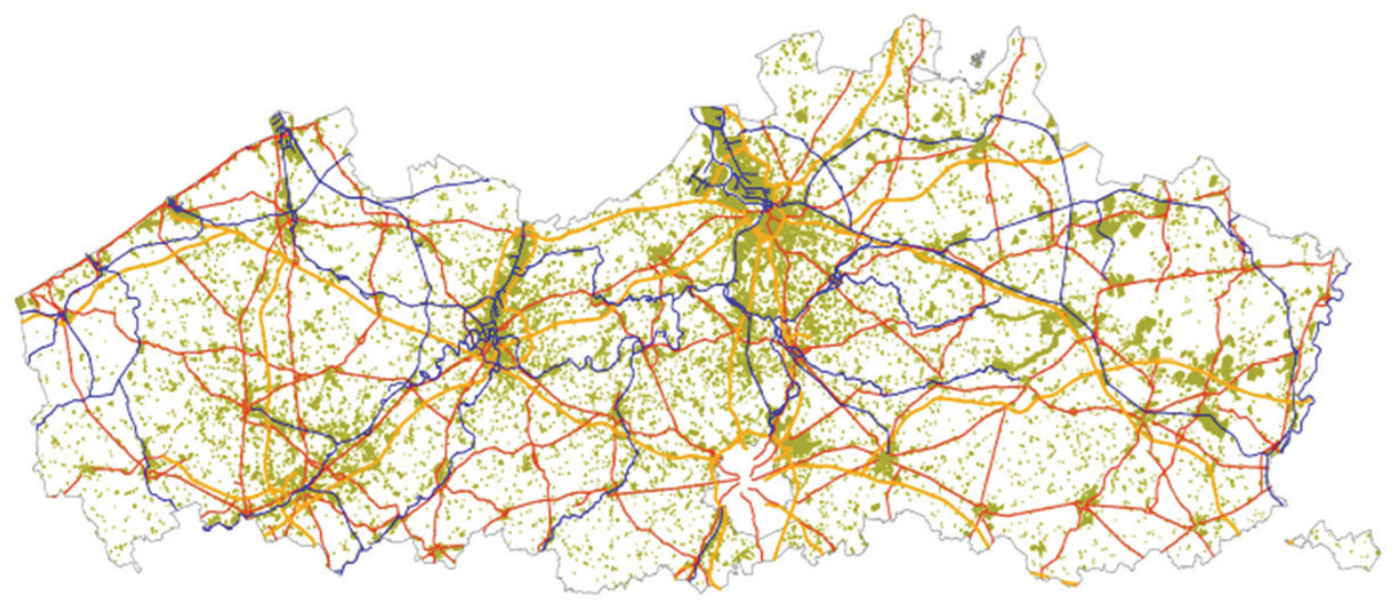

FIGURE 1. Explored contaminated sites in Flanders from the Land register

remediation of new soil contamination. There are several instruments for the implementation of the mentioned policy, and one of them is Soil Information Register, containing quantitative and analytical parameters of soil excavated from contaminated sites in Flanders. The Soil Information Register contains the so called "Soil certificate", available for each of the specified plots with all necessary information about the land parcel. The entire system is carried out by the Waste Agency of Flanders (OVAM). Inventory of potentially polluted land is carried out at the lower administrative levels such as counties (Figure 1).

New contaminated sites imply that they have been contaminated after 28 October 1995 and that they should be remediated if the contamination exceeds the remediation standards set by law. For the historical pollution that has occurred before 29 October 1995 there are remediation obligations if there is a serious health and environmental risk, all in accordance to certain priorities. The obligation to implement and finance the remediation is on the operator, and in the situation when he is not known, the user of land. In a case when the operator does not possess sufficient resources, it can apply for support from the
Flemish government. Standards for remediation (limit and target values) are set by the Flemish government, and they must be below the values that represent a risk to health and to the environment. If it is determined that soil contamination exceeds the given thresholds, a more detailed study of the soil is immediately carried out. To carry out exploration activities on the site, the Flemish government empowers individuals and legal entities called "experts for soil remediation" (currently in Flanders there are 72 legal persons or companies accredited for the soil survey). Experts for remediation conduct a preliminary investigation of soil and groundwater, a more detailed investigation, remediation, and preparation of the final remediation report. By 2013 Flanders has issued over 3 million soil certificates, over 32 000 preliminary soil testing and over 9500 detailed examination have been carried out. More than 4000 remediation projects have been approved, 3500 were initiated and around 2200 were completed.

\section{The Current State of the Management of Contaminated Soils in Croatia}

Implementation of the management of contaminated soil according to IED, requires the 
establishment of a functional operational, multilevel system at the country scale (Figure 2 ).

JURISDICTION (MINISTRY)

LEGISLATION

REGISTER OF CONTAMINATED SITES

\section{CERTIFIED SOIL EXPERTS}

FIGURE 2. Hierarchical components of the soil management system

In the above presented hierarchical structure, the first requirement in the establishment of soil management system presents a clear definition of concerning jurisdictions between ministries. In the current practice in Croatia, for issues related to the soil legislation, the institution in charge is the Ministry of Agriculture where the necessary capacity to implement the obligations has been partially developed. The Ministry of Agriculture through the Agricultural Land Agency is responsible for the operational implementation of the control of soil condition, but mainly on agricultural land (i.e. soil contamination in the urban areas, and nearby industrial facilities, on the nonagricultural land is beyond the scope of this ministry). On the other hand the responsible entity for the implementation of general environmental strategy, policies of sustainable development together with the protection of environmental components such as air, soil, water, sea, biodiversity, environmental directives such as IEDs, according to the Law on Organization and Jurisdiction of ministries and other central government bodies [24] is the Ministry of Environmental and Nature Protection, together with its operating body, the Environmental Protection Agency. At the present neither the Ministry of Environmental and Nature Protection nor the Environmental
Protection Agency have developed a sufficient capacity for self- performing and leading of the operational implementation of contaminated soil management by an IED. Also, due to the relatively strong fragmentation of environmental activities between ministries in Croatia the responsible entity for monitoring of groundwater quality at urban sites (what is also required by IED) is within the scope of the Ministry of Health (Public Health) and Croatian waters.

According to IED (Article 22), activities that involve use, production or emissions of hazardous substances that can contaminate soil and groundwater at the site, require the preparation and submitting of a report on the initial state (baseline report) before starting of the operation (industrial process) or before renewal of the environmental permit. However, until today the Croatian legislation concerning soil has not yet defined what presents "soil contamination", what are the pollutants that should be concerned in respect to IED, and also there are no critical limits set. The legislation has not yet defined values that represent "significant pollution" or "significant risk" which exceeds the requirements for the remediation of soil. Although the new law on environmental protection tackles a lot of subjects inside IED, issues associated with contaminated soils are mostly neglected and insufficiently considered so there is a strong need for urgent development of the new legislative framework that will accurately define the obligation and procedures for the management of contaminated soil.

With respect to the Soil pollution register, the Environmental Protection Agency has prepared the GEOL database in 2006 as part of the Croatian Soil Information System (HIST). GEOL is geo-referenced (GIS) database, which includes data and information on potential and identified contaminated sites, pollutants on confirmed contaminated sites, and the status of implementation of remediation of contaminated sites. A linkage of the GEOL database with the database of Landfill Inventory and the data in the 
Register of installations in which dangerous substances are present (RPOT) has been performed. Given the current state, the CEA has made a significant step towards building a comprehensive IT - spatial platform, which provides a good basis for further development of management system of contaminated sites in Croatia. Next steps require continuous replenishment of established database structure with quantitative parameters of soil, depending on the source of contamination on all relevant locations for IED what is likely to represent a time consuming and financially demanding process.

\section{Ambiguities in the Current Soil Mana- gement Practice in Croatia (Examples from Urban Zones, Agriculture, Forestry and Natura2000)}

\section{The City of Zagreb (Industrial and Urban Pollution)}

The Environmental Protection Report of the city of Zagreb (2009) highlighted the problem of inputs of certain pollutants into Zagreb aquifer due to the very probable excessive pollution of soils in some of the locations in the city area [25]. Zagreb aquifer is the main source of drinking water supply for metropolitan inhabitants. Undoubtedly, for the protection of human health, monitoring of the drinking water quality by authorized public health laboratories is carried out. However, according to acquired results, Zagreb aquifer is a very vulnerable environmental system, highly sensitive to contamination. In the metropolitan area, on a number of wells pollution has been detected which indicates contamination of soils (Figure 3). The most common pollution is caused by heavy metals such as lead as shown in the analysis of groundwater in the area of Zapruđe, Prečko, Kosnice and Ivanja Reka. Contamination by manganese (Petruševec, Sašnjak and Kosnica) and mercury (Kosnica) is also very common in groundwater. In addition to pollution by heavy metals, a specific problem represents atrazine, which have been found in groundwater in the agricultural area near
Buzin. Due to excessive inputs of pollutants into groundwater, within 10 years, the city of Zagreb remained without water supply wells that provided around 114.5 million litters of drinking water per day (what is equal to the needs of the city of 350,000 inhabitants).

The case of Zagreb aquifer presents sterling example of the lack of a systematic approach for the management of contaminated soil, which leads to the pollution of groundwater and ultimately resulting in the closure of water wells. Systematic approach, which would reduce the long-term pressure and the risk of contamination can be sought by transposing and implementing good environmental practice contained in IED through the following steps: a) increased engagement of the city administration to identify contaminated sites and associated pollutants; b) determining the status of soil contamination by authorized soil experts; c) establishing threshold values for soil that do not pose a significant risk to health and the environment (at the state ministerial level); d) the gradual conduction of remediation on established risk sites; e) the adoption of comprehensive legislation that will define all previous measures.

\section{Zadar County (Agricultural Production)}

The state of soil pollution of Zadar County, which is mandatory for production of the County Environmental Status Report (2012), was assessed using geochemical atlas of Croatia [26]. The obtained results confirmed existence of elevated concentrations of arsenic, cadmium, chromium and manganese (Figure 4), the pollutants which are mostly highly toxic to humans, plants and animals. Elevated concentrations of arsenic, chromium and manganese in the area are formed by nature, they are related to geological bauxite deposits and their weathering, while the most possible origin of cadmium are local sources of pollution. According to the existing legislation (Regulation on the protection of agricultural land from pollution [10] and valid critical limits (maximum allowable concentrations), large areas in the County can be classified 


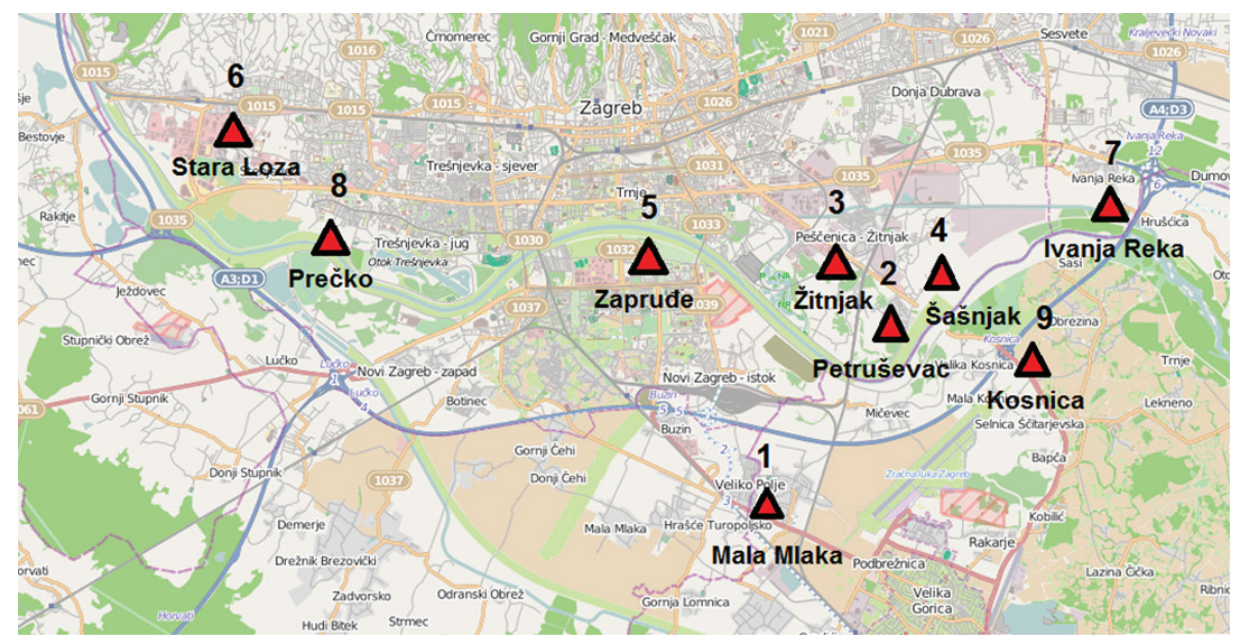

FIGURE 3. Locations of polluted water supply wells in the city of Zagreb (1. High and constant concentrations of atrazine, chromium, lead, cadmium and copper; 2. High concentrations of manganese; 3. High and constant concentrations of organic solvents; 4. High manganese concentrations; 5 . Periodically high concentrations of lead; 6 . High concentrations of lead, iron, manganese and trichloroethane solvent; 7. Higher concentration of nitrates, lead and organic solvents; 8 . Excess of bacteria, cadmium and lead; 9. High concentrations of iron, manganese, zinc, lead and mercury)

as "contaminated" due to the high content of these elements in the soil. It is particularly important to emphasize high concentration of chromium in the wider area of Ravni kotari, which are very famous for their intensive agriculture. According to current regulations and established critical limits, soil in the vicinity is classified as "contaminated" and it is questionable if these areas can be used for "Ecological agricultural production" and fulfil the requirements for obtaining subsidies for ecological farming. However, since these high concentrations are mainly of natural origin, in the area historically committed to agriculture, it is questionable how much in reality these elevated concentrations of chromium represent a "significant risk" to health and the environment, and whether it is necessary to constrain subsidies for food production because of that historical "pollution" and vagueness of existing legislation. In drafting of the new regulations concerning soil contamination, one must take into account the natural load of polluting substances in the soil as well as their realistic environmental risk.
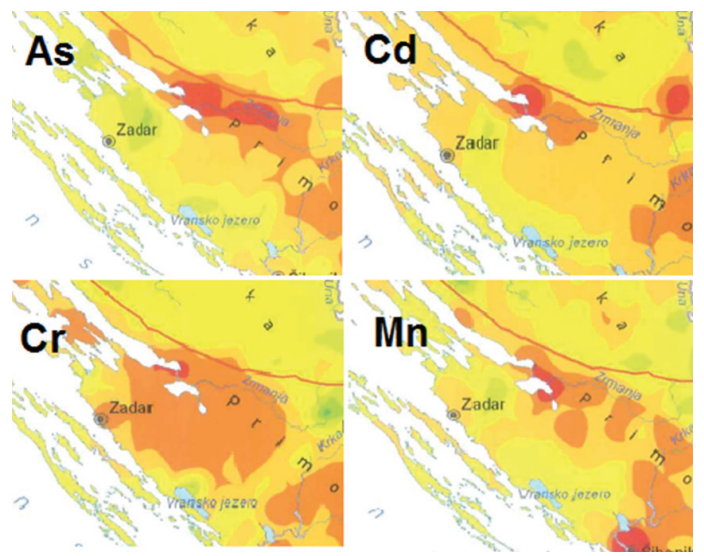

FIGURE 4. The load of arsenic, cadmium, chromium and manganese in the area of Zadar County [20]

\section{Vukovar - Srijem County (Spačva forest - Forestry, Natura2000)}

Spačva forest in Vukovar-Srijem County presents the largest complex of lowland oak (Quercus robur) forests in Croatia and it is partly included in Natura 2000 network. Particularly valuable habitats are in the south-western 
part of Spačva which consists of the protected riparian mixed forests of Quercus robur, Ulmus laevis, Ulmus minor, Fraxinus angustifolia, alluvial forests (Alno-Padion, Alnion incanae, Salicion alba), oak-hornbeam forests and natural eutrophic waters with Hydrocharition or Magnopotamion vegetation. However, a large part of these protected habitats are located in the areas with polluted soil with a high content of chromium and nickel (Figure 5), due to a historical sedimentation by flooding. Although in the above case it is not realistic to perform any kind of remediation measures, the soil management practice and legislation should at least consider the risk on the environment and habitats which potentially could presents these elevated concentrations in soils. Separate "physical" protection of naturally valuable areas against man made influence have only full meaning if the components of environment such as soil are also considered and protected by respective regulations. One cannot establish physical barriers around naturally protected areas, there will always be the pressure of emissions of pollutants from the surroundings and therefore the proper implementation of the Habitat directive and nature protection should aim on development of regulation and management system also related to the protection of soils and reduction of environmental risk to air, water and soils at the Country level.

\section{CONCLUSION}

Soil protection in the EU is carried out by various sectorial directives where soil is not a core subject. Soil protection is particularly orientated on preventing the contamination of surface and groundwater.

- Some of the Directives which partly and indirectly consider soil protection Water framework directive (Directive 2000/60/ EC concerning Water \& Directive 2006/118/EG concerning Groundwater) with the aim of obtaining good water status until 2015 and improving of groundwater quality. This directives aims on production watershed management plans with identification of point sources of contamination.

- The EU Directive on environmental liability (Directive2004/35/CE concerning environmental liability) aims to prevent and remedy environmental damage, and in particular soil destruction. This Directive regulates how investors and performers of various harmful activities in the environment must take the necessary measures to prevent adverse impacts on the soil.

- The protection of soil from pollution is regulated by the Directive on industrial emissions (Directive 2010/75/ CE concerning Industrial Emissions, IED). IED Directive sets the obligation on the industrial operator before the start of production to prepare a report on the initial state of soil as a necessary requirement for obtaining the environmental permit. It sets obligations for the monitoring of soil and the groundwater status in the

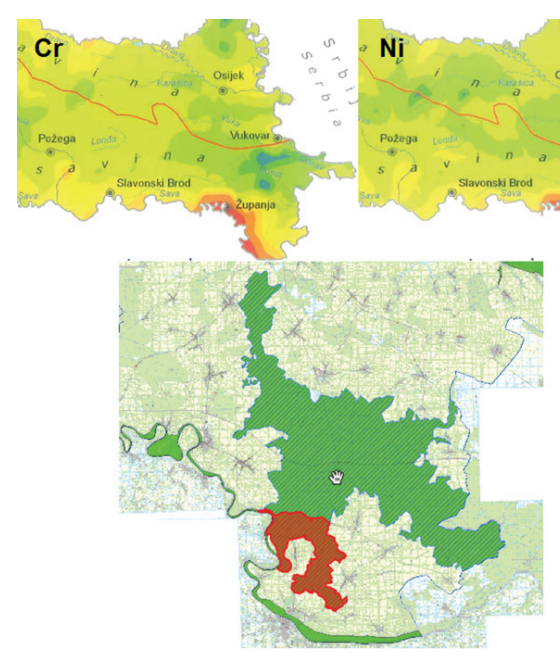

FIGURE 5. High concentrations of chromium and nickel [20] in the Natura 2000 protected area of Spačva forest 
location of an industrial facility for a period of ten (soil) and five years (groundwater). After the cessation of production, and in the case of exceeding critical limits of pollution, the operator is obliged to perform remediation or restitution of land in the state as it was at the beginning of production.

Management of contaminated soil according to IED requirements oblige the Croatian government to establish a complex system at multiple levels. First, it requires better definition of responsibilities between ministries; in particular, between theMinistry dealing with environmental protection and sustainable development and the Ministry dealing with agriculture. IED requires enactment of adequate legal basis (i.e. Soil protection act) and the establishment of operational instruments for the implementation of soil protection, such as register of contaminated soil and the accreditation of soil remediation experts.

\section{Acknowledgements}

This study was produced in the framework of intergovernmental cooperation between Croatia (Ministry of Environmental and Nature protection) and Flanders (Public Waste Agency of Flanders OVAM) on the issue of soil protection. It emerged as a result of participation of principal author in a project "Technical assistance and analysis of the need for soil management policy in Croatia", conducted by the Flemish consulting company Ecorem (www.ecorem.be), with the financial contribution of the Flemish government.

\section{REFERENCES}

1. CROATIAN PARLIAMENT 2012 Criminal Act (in Croatian). Official Gazette 125/11, Zagreb, Croatia. URL: http://narodne-novine.nn.hr/default. aspx (15 December 2013)

2. CROATIAN PARLIAMENT 2013 Environmental Protection Act (in Croatian). Official Gazette 80/13, Zagreb, Croatia. URL: http://narodne-novine.nn.hr/ default.aspx (15 December 2013)

3. KOMLENOVIĆ N, MAYER B, RASTOVSKI P 1991 Introduction of Heavy Metals by Polluted Flood Waters into Soils of Lowland Forests of East Slavonia (in Croatian with English summary). Sumar list 115 (3-5): 131-149

4. MAYER B, PEZDIRC N 1991 Heavy Metals (Pb, Zn, $\mathrm{Cu}$ ) in the Soils of Lowland Forests in North-West Croatia (in Croatian with English summary). Sumar list 114: (6-8): 251-259

5. ROMIĆ M, ROMIĆ D 2003 Heavy metals distribution in agricultural topsoils in urban area. Environ Geol 43 (7): 795-805

6. VUČKOVIĆ I, ŠPIRIĆ $Z$, STAFILOV T, KUŠAN V 2013 Moss biomonitoring of air pollution with chromium in Croatia. J Environ Sci Heal A 48 (7): 829-834. DOI: http://dx.doi.org/10.1080/1093452 $\underline{9.2013 .744661}$
7. VUČKOVIĆ I, ŠPIRIĆ Z, STAFILOV T, KUŠAN V 2012 Biomonitoring of air pollution with zinc in Croatia studied by moss samples and ICP-AES. Contributions (Macedonian Academy of Sceince and Arts, Section of Mathematical and Technical Sciences) 33 (1-2): 47-60.

8. ŠPIRIĆ Z, FRONTASYEVA M V, STEINNES E, STAFILOV T 2012 Multi-element atmospheric deposition study in Croatia. Int J Environ An Ch 92 (10): 12001214. DOI: $\mathrm{http}: / / \mathrm{dx}$.doi.org/10.1080/03067319.2 $\underline{011.561336}$

9. CROATIAN PARLIAMENT 2013 Agricultural Land Act (in Croatian). Official Gazette 152/08, 21/10, 39/13, Zagreb, Croatia. URL: http://narodnenovine.nn.hr/default.aspx (12 December 2013)

10. MINISTRY OF AGRICULTURE 2014 Regulation on the protection of agricultural land from pollution (in Croatian). Official Gazette 32/10, 9/14, Zagreb, Croatia. URL: http://narodne-novine.nn.hr/default. aspx (30 January 2014)

11. MINISTRY OF AGRICULTURE 2013 Regulation on standards for determination of exceptionally valuable arable (P1) and valuable arable (P2) agricultural land (in Croatian). Official Gazette 53/10, 151/13, Zagreb, Croatia. URL: http://narodnenovine.nn.hr/default.aspx (30 January 2014) 
12. MINISTRY OF AGRICULTURE, FISHERIES AND RURAL DEVELOPMENT 2010 Regulation on the methodology for the monitoring of agricultural land (in Croatian). Official Gazette 60/10, Zagreb, Croatia. URL: http://narodne-novine.nn.hr/default. aspx (30 November 2013)

13. MINISTRY OF REGIONAL DEVELOPMENT, FORESTRY AND AND WATER MANAGEMENT 2010 Regulations on monitoring state of damage of forest ecosystems (in Croatian). Official Gazette 67/10, Zagreb, Croatia. URL: http://narodne-novine.nn.hr/ default.aspx (30 November 2013)

14. CROATIAN PARLIAMENT 2012 Forest Act (in Croatian). Official Gazette 140/05, 82/06, 129/08, 80/10, 124/10, 25/12, 68/12, Zagreb, Croatia. URL: http://narodne-novine.nn.hr/default.aspx (12 December 2013)

15. CARDON M 2012 Soil Policy at EU level. Presentation from the workshop in Public Waste Agency of Flanders - OVAM, Mechelen, Belgium, 11-14 September 2012

16. EUROPEAN COMISSION 2006 Thematic Strategy for Soil Protection (COM (2006) 231). URL: http://eur-lex.europa.eu/legal-content/EN/ TXT/?uri=CELEX:52006DC0231 (5 November 2013)

17. EUROPEANCOMISSION2006 Proposal for a Directive of the European Parliament and of the Council establishing a framework for the protection of soil and amending Directive 2004/35/EC (COM (2006) 232). URL: http://eur-lex.europa.eu/LexUriServ/ LexUriServ.do?uri=COM:2006:0232:FIN:EN:PDF (6 November 2013)

18. COUNCIL OF THE EUROPEAN UNION 1992 Council Directive 92/43/EEC of 21 May 1992 on the conservation of natural habitats and of wild fauna and flora. Official Journal L 206, 22/07/1992, pp 7-50. URL: http://eur-lex.europa.eu/LexUriServ/ LexUriServ.do? uri=CONSLEG:1992L0043:2007010 1:EN:PDF (3 September 2013)

19. COUNCIL OF THE EUROPEAN UNION 2009 Council Regulation (EC) No 73/2009 of 19 January 2009 establishing common rules for direct support schemes for farmers under the common agricultural policy and establishing certain support schemes for farmers, amending Regulations (EC) No 1290/2005, (EC) No 247/2006, (EC) No $378 / 2007$ and repealing Regulation (EC) No 1782/2003. Official Journal L 30, 31/01/2009, pp 16-99. URL: http://eur-lex.europa.eu/legal-content/ EN/TXT/?uri=uriserv:OJ.L .2009.030.01.0016.01. ENG (5 September 2013)
20. EUROPEAN COMISSION 2009 Commission Regulation (EC) No 1122/2009 of 30 November 2009 laying down detailed rules for the implementation of Council Regulation (EC) No $73 / 2009$ as regards cross-compliance, modulation and the integrated administration and control system, under the direct support schemes for farmers provided for that Regulation, as well as for the implementation of Council Regulation (EC) No $1234 / 2007$ as regards cross-compliance under the support scheme provided for the wine sector. Official Journal L 316, 2/12/2009, pp 65-112. URL: http://faolex.fao.org/docs/pdf/eur91401.pdf September 2013)

21. THE EUROPEAN PARLIAMENT AND THE COUNCIL OF THE EUROPEAN UNION 2010 Directive 2010/75/ EU of the European Parliament and of the Council of 24 November 2010 on industrial emissions (integrated pollution prevention and control). Official Journal L 334, 17/12/2010, pp 17-119. URL: http://eur-lex.europa.eu/LexUriServ/LexUriServ. do?uri=0J:L:2010:334:0017:0119:en:PDF (11 September 2013)

22. GOMMEREN E 2012 Soil management in Flanders. Presentation from the workshop in Public Waste Agency of Flanders - OVAM, Mechelen, Belgium, 11-14 September 2012

23. Decree on soil remediation and soil protection. URL: http://navigator.emis.vito.be/milnav-consult/ faces/doorlopendeTekstPdf.jsp? print $=$ false (14 September 2013)

24. CROATIAN PARLIAMENT 2013 Law on Organization and Jurisdiction of ministries and other central government bodies (in Croatian). Official Gazette, 150/11, 22/12, 39/13, Zagreb, Croatia. URL: http:// narodne-novine.nn.hr/default.aspx (30 November 2013)

25. SOLLITTO D, ROMIC M, CASTRIGNANÒ A, ROMICD, BAKIC H 2010 Assessing heavy metal contamination in soils of the Zagreb region (Northwest Croatia) using multivariate geostatistics. Catena 80 (3): 182-194. DOI: http://dx.doi.org/10.1016/j. catena.2009.11.005

26. HALAMIĆ J, MIKO S (eds) 2009 Geochemical atlas of the Republic of Croatia. Croatian geological survey, Zagreb, Croatia, $87 \mathrm{p}$ 